\title{
The Impact of Remuneration and Modernization Tax Information System on Employee Performance
}

\author{
Bunyamin Bunyamin, Wiyarni Wiyarni*, Sudaryoto Sudaryoto \\ Post Graduate Program \\ STIE Malangkucecwara \\ Malang, Indonesia \\ *wiyarni08@gmail.com
}

\begin{abstract}
This study aims to determine and analyze the effect of remuneration and modernization of tax information systems on employee performance at the tax service office in Malang, East Java, Indonesia. The analysis in this study uses multiple linier regressions to answer research problems. This study has 84 respondents. The results of this study show that remuneration and modernization of the tax information system has a significant effect on performance of employees in the Malang tax service office. This finding is indicated by the results of the $F$ test $(F$ count) of 10,140 which is greater than the obtained $F$ table value 3,109. This finding is expected to give contribution in decision making process related with policy of remuneration and modernization information system in tax service office.
\end{abstract}

Keywords: remuneration, modernization tax information system, employee performance

\section{INTRODUCTION}

Human resources (HR) have an important role in determining the success of an organization. Every action taken in each activity is determined by the existence of human resources who are members of the organization. Human resources in organizations must be able to show professional performance because the performance performed by members will have an impact on organizational performance which in turn will have an impact on the organization's image. Performance is the result of work in quality and quantity achieved by a person in carrying out his duties in accordance with the responsibilities given to him. Employee performance is a result of work achieved by a person in carrying out the tasks assigned to him based on skills, experience and sincerity as well as time [1]

Employee performance is influenced by many factors, possibly one of which is remuneration. Remuneration is something that an employee receives in return for the contribution he has made to the organization where he works. Remuneration includes all rewards in the form of money or goods, both routine and non-routine, as well as those given directly or indirectly. Remuneration is considered a tool to realize the vision and mission of the organization because the remuneration itself aims to attract capable and experienced employees, maintain qualified employees, motivate employees to work more effectively, motivate positive behavior formation, and make a tool to control expenditure, where these are factors that can help to achieve the organization's vision and mission [2].

One of other factor that influences employee performance is the modernization of tax information systems especially in the field of taxation. Gradually, there is the Directorate General of Tax Information System (SIDJP) at the Directorate General of Taxes that uses a centralized database to support all activities. The purpose of the establishment of the Directorate General of Tax Information System (SIDJP) is to be able to produce taxpayer profiles that can be a supporting tool for the creation of accurate taxpayer data, by mobilizing the participation of various parties in monitoring taxpayer data. The process that has been carried out in the framework of modernizing the Directorate General of Taxes can be seen through various programs that have been carried out, including: e-reg, e-spt, e-filling, e-nofa, e-billing [3]. As well as the modernization of the Personnel, Finance and Asset Information System (SIKKA), this system is separate from the SIDJP which has been there. SIKKA is an application that is used to report employee data and activities as well as financial activity data in the Tax Office. Modernization of tax information systems is needed to improve the ability of the Directorate General of Taxes to oversee the implementation of applicable tax provisions with the principles of Good Governance. The application of a modern taxation information system will bring consequences to the occurrence of fundamental changes both concerning the organizational structure and the service paradigm to taxpayers.

This study aims to explore the effect of remuneration and modernization tax information system on employee performance. The object of this study is Malang tax service's employees. The results of this study are expected to give contribution in decision making process related with remuneration and modernization information system in tax service office.

\section{LITERATURE REVIEW}

\section{A. Remuneration}

Remuneration plays an important role in building employee performance in order to work optimally so that it will have an impact on the services provided to the community. Long \& Peter stated that work instrumentalism significantly reduces the 
positive effect of training on job satisfaction while boosting the positive effect of remuneration on job satisfaction [4]. The study also stated that there is no evidence for an interaction between instrumentalism and employee involvement. Judge et al. stated that pay level was positively related to job satisfaction [5]. However, several researchers have found that the strength the relationship between pay level and job satisfaction is varies from person to person, depending on individual differences in the value of work $[6,7]$.

In practice, remuneration has several roles [8]. These roles are first, meeting economic needs; employees receive remuneration in the form of salaries, wages or other forms for their economic needs. Second, providing better remuneration will be able to encourage employees to work more productively. Third, advancing the organization or company; the higher the remuneration given to employees is expected to build high performance of employees so that the company will be growth advance. Fourth, demonstrate balance and justice; this is expected to create a balance between input and output.

Remuneration is considered as giving rewards to employees who have contributed to the company as well as punishment to employees who do not contribute to the company. In order to be able to support the implementation of competency-based human resource systems, the provision of benefits must be associated with an increase in competency demonstration by employees in carrying out work. Remuneration has several objectives [9]. The objectives are attracting prospective employees who are qualified and have competencies that are in accordance with the competencies required by the company; make employees who excel and who make the biggest contribution to the company can feel at home working in the company and increase employee work motivation.

\section{B. Modernization Tax Information System}

The process towards the modernization information system of the Directorate General of Taxes can be seen through a variety of programs that have been carried out, including: ereg, e-spt, e-filling, e-nofa, e-billing [3]. In order to increase the data accuracy, speed and expediting work, the Directorate General of Taxes in Indonesia has several information systems used by existing work units, such as the Tax Information System (SIP) in KPP, Geographic Information System (GIS) and Tax Object Information Management System (SISMIOP) at KPPBB. Because the work process and service in modern KPP is for all types of taxes so that the information system is designed to be able to accommodate all [10]. Although in its development from mid-2013, the UN has been submitted to the Regional Government, but for the object of PBB Tax P3 (Forestry, Plantation and Mining) still managed by the central government in this case DGT.

Chang Lee et al. stated that users of tax filling system in the two countries felt differently in the factors, such as ease of work, adequacy of the amount of information, display speed, convenience to life, job productivity, and help service [11]. Although the tax system in Turkey is complex, the Turkish users did not find that the tax filing system is difficult. It means difficult to use. It may be the users are accounting professionals who frequently use the system. Modernization of tax information systems is needed to improve the ability of the Directorate General of Taxes to oversee the implementation of applicable tax provisions with the principles of Good Governance. The application of a modern taxation information system will bring consequences to the occurrence of fundamental changes both concerning the organizational structure and the service paradigm to taxpayers. In practice the Information System of the Directorate General of Taxes has various characteristics, including:

- All administrative activities are carried out through the latest technology-based administration system, from registering NPWPs through the e-registration application.

- All Taxpayers are required to pay through the payment recipient office / Perception Bank and can make payments online through e-billing.

- All Taxpayers are required to report their tax obligations on PPh using computer media (e-SPT) and (e-Invoice) for VAT applications.

- Monitoring of taxpayer compliance is carried out intensively by utilizing taxpayer profiles through the Approweb application, SI-DJP application, DJP Portal application.

In practice, the modernization of tax information systems made by the Directorate General of Taxes is useful for facilitating taxpayers in four ways, namely [12]:

1) $e-S P T$ (Electronic Notice): Electronic SPT or e-SPT is an application (software) made by the Directorate General of Taxes to be used by Taxpayers in submitting SPT. The e-SPT application is also to be used by taxpayers (WP) in reporting tax returns or notices (to make it easier and less wasteful of paper).

2) e-Filling: E-Filing is a way to deliver a notification letter that is done through an online system and a real team. According to PMK Number 152 / PMK.03 / 2009 Article 1 Paragraph 6, e-filling is a method of submitting SPT or Notification of Annual Tax Return Extension that is conducted online in real time through the website of the Directorate General of Taxes (www.pajak.go.id) or Application Service Provider (ASP). E-Filling according to the Directorate General of Tax Regulation Number PER-1 / PJ / 2014 is a way to submit annual SPT electronically which is done online and real time via the internet on the website (www.pajak.go.id) or through an Application Provider Company or Application Service Provider (ASP). With the e-filling, in general, it is very profitable for taxpayers, to provide taxpayers with ease in reporting SPTs at a cost that tends to be cheaper than manually and with faster processing because taxpayers record their own notification letters so they can be more accurate, effective and efficient. This is a new breakthrough in reporting SPT reports rolled out by DGT to make taxpayers easier and more comfortable in carrying out their obligations.

3) e-registration: With the guidelines of the Directorate General of Taxation Number 24 / PJ / 2009 E-Registration or 
- Loyalty; it means loyalty to the work assigned to the employee.

registration of Taxpayers and / or inauguration of Taxable Entrepreneurs and changes in data of Taxpayers and / or Taxable Entrepreneurs through directly connected internet online with the Directorate General of Taxes. According to Director General of Taxation Regulation Number PER-20 / PJ / 2013 E-Registration is a system of registration of taxpayers and inauguration of taxable entrepreneurs online. For taxpayers who have registered and want to change the taxpayer's data, they can use the service. E-registration is intended for private taxpayers and entities who will register themselves to obtain a Taxpayer Identification Number (NPWP) and / or inauguration of Taxable Entrepreneurs (PKP).

4) e-Billing: Billing system is a system that publishes billing codes for payments or deposits of state revenues electronically, without the need to make a manual deposit (SSP) (www.pajak.co.id). Payment transactions or tax deposits through e-billing systems can be done through bank / perceptual posters, automatic teller machines (ATM), internet banking and EDC (Electronic data Capture), which are tools used for debit or credit card transactions that are connected online with the system or perception bank network.

\section{Employee Performance}

Performance is the result of work achieved by employees or a group of employees in an organization carried out in accordance with the authority and responsibility of each in an effort to achieve the objectives of the relevant organization legally and not violate the law and in accordance with morals and aesthetics. As a result of work, performance is considered a work performance that is assessed in terms of quality and quantity for the achievement of an employee in carrying out tasks that are in accordance with the responsibilities given. Performance is the implementation of planning that has been prepared and carried out by human resources who have the ability, competence, motivation and interests [13].

Employee performance is the result of work obtained by an employee in quality and quantity in carrying out duties according to the responsibilities given to the employee [14]. Employee performance is also interpreted as a result that someone wants to achieve in carrying out work tasks that are owned that affect the contribution given to the company where someone works. Employee performance is a result of work achieved by a person in carrying out the tasks assigned to him based on skills, experience and sincerity as well as time [1]

Employee performance can be known to be good or bad if there is an assessment. Assessment of employee performance is an assessment activity towards achieving certain targets that have been derived from the existence of the organization's strategic goals. In addition, performance appraisal is considered as an effort to evaluate a person's success or failure in carrying out a task that is his responsibility. There are aspects that become judgments in carrying out an assessment of employee performance. These aspects consist of [15]:
- Work performance; is the result of work achieved by an employee in carrying out the tasks assigned to the employee. In general, employee performance is influenced by the existence of skills, experience, and sincerity of employees in the work they are responsible for.

- Responsibility; is the ability of an employee to complete the work submitted to the employee as well as possible and on time and have the courage to bear the risk of decisions on the actions taken.

- Obedience; is the ability of an employee to comply with all regulations given and stipulated by the company, as well as the ability to not violate existing rules.

- Honesty; is the sincerity of an employee in carrying out the duties and the ability to not abuse the authority given to the employee. There are elements in honesty, namely: carry out the task with sincerity; not abusing authority and always provide reports to superiors about the results of work in accordance with the facts that occur in the field.

- Cooperation; is the ability of an employee to collaborate with others in completing a predetermined task. This is done in order to achieve greater usability and results. In cooperation there are elements which consist of: understanding others assignments that have relationship with his/her jobs; appreciate with others opinions; has ability to adjust with others opinions; considering and accepting others opinions; has ability to work in a team; and agree with the decisions.

- Initiative; is the ability of an employee to take a decision, steps or carry out an action that is needed in carrying out basic tasks without having to wait for orders in advance from the boss. There are several elements of the initiative which consist of: making decision without waiting for leader instructions; trying to find new methods to get better benefits; and trying to give good suggestion to leader voluntarily.

- Leadership; is the ability of an employee to convince others so that the other person can be maximally mobilized in carrying out the main tasks. There are elements contained in leadership consisting of: understanding the job; have ability to make decision appropriately; have ability in delivering opinion clearly; have ability to make priorities; have ability to take action fairly; develop the teamwork; understanding the ability of others; and motivate their team.

Performance evaluation is a tool that can be used to improve decision making quality and accountability in giving evaluation toward achievement based on established indicators. 
- Obedience; is the ability of an employee to obey all regulations given and determined by the company, as well as the ability not to violate existing rules.

- Honesty; is the sincerity of an employee in carrying out the duties and abilities not to abuse the authority given to the employee.

- Cooperation; is the ability of an employee to collaborate with other people in completing a predetermined task.

- Initiative; is the ability of an employee to take a decision, steps or carry out an action that is needed in carrying out the main tasks without having to wait for orders from the boss.

- Benefits that given to the employees based on their performance.

- Facilities that given to the employees, such as car, health insurance.

\section{B. Modernization Tax Information Systems}

Modernization tax information systems are defined as the program that used by The Directorate General of Taxes. Those programs are e-SPT, e-Filling, e-Registration, e-Billing, SIDJP (information systems of tax administration), and SIKKA.

- E-SPT is a program that developed by the Directorate General of Taxes for taxpayers to submit SPT.

- E-Filling is a program that used to distribute tax notification through online systems.

- E-Registration is a program that used by taxpayers to register and to change their data through online systems.

- E-Billing is an electronic system that issue billing codes for tax payments.

- SIDJP is an information system of tax administration in the taxation department by using hardware and software that linked to the head office through networks.

- SIKKA is an application that used to report the data and activities of the employees in the tax department.

\section{Employee Performance}

Employee performance is defined as a result of work achieved by a person in carrying out the tasks assigned to him based on skill, experience and sincerity as well as time. This variable has 8 indicators. These indicators are loyalty, work performance, responsibility, obedience, honesty, cooperation, initiative, and leadership.

- Loyalty is loyalty to the work assigned to the employee

- Work performance; is the work achieved by an employee in carrying out the tasks assigned to the employee.

- Responsible; is the ability of an employee to complete the work submitted to the employee as well as possible and on time and has the courage to bear the risk of decisions taken for actions taken.
- Leadership; is the ability of an employee to convince others so that other people can be mobilized to the maximum in carrying out basic tasks.

The population in this study is all Malang KPP employees totaling 105 people. The sample size was obtained using the Slovin formula with a critical value of $5 \%$, so the sample size was 84 people. The data validity technique in this study was carried out with two tests, namely the validity test and the reliability test. In the validity test, if the correlation value between the score of a variable item and the total score of a variable is equal to 0.3 or more (at least 0.3 ) then the instrument item is valid. The reliability test will be carried out using the Cronbach's alpha $(\alpha)$ statistical test. The studied variable is reliable if the Cronbach's alpha $(\alpha)$ value is above 0.6 .

Data analysis used in this study is the classical assumption test, multiple determination coefficient analysis, multiple linear regression analysis and hypothesis testing. Before the regression model is used to test hypotheses, a classical assumption test is needed to ensure that the model meets the BLUE (Best Linear Unlimited Estimator) criteria. The classic assumption tests used in this study are as follows: normality, multicollinearity, and heteroscedasticity, the coefficient of determination is used to indicate the magnitude of the contribution of $\mathrm{X}$ variables to $\mathrm{Y}$ variable. The value of $\mathrm{R}^{2}$ or $\mathrm{r}^{2}$ is between 0 and 1 which means that if $R^{2}$ or $r^{2}=1$, it means that the independent variable is able to explain the dependent variable $100 \%$ and the model approach used is right. If $\mathrm{R}^{2}$ or $\mathrm{r}^{2}$ $=0$, it means that the independent variable is not able to explain the dependent variable. The higher the value $\mathrm{R}^{2}$ or $\mathrm{r}^{2}$ and or the closer to 1 , the better is the model used. Multiple linear regression analysis is a statistical technique that can be used to analyze the relationship between one single dependent variable and several independent variables. The multiple linear regression models in this study was prepared using unstandardized B regression coefficient values (for simultaneous influence analysis) and standardized beta (for partial effect analysis). Finally, hypothesis testing in this study is carried out to analyze and draw conclusions on the problem under study. This test is intended to determine whether there is an influence of the independent variable on the dependent variable. The hypothesis test used is the $\mathrm{F}$ test and $\mathrm{T}$ test. 


\section{RESULTS AND DisCUSSION}

\section{A. Descriptive Statistic}

The respondents in this study were 84 employees from tax office (KPP) Madya, Malang, East Java, Indonesia. In this study the characteristics of respondents are divided into, gender, age, and length of work. The characteristics of the respondents in this study are as follows:

\section{1) Respondents based on gender}

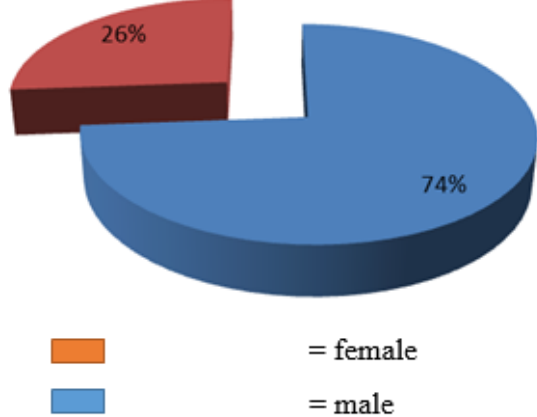

Fig. 1. Respondents based on gender.

Based on the figure 1, it can be concluded that most of the respondents are male.

2) Respondents based on age: The age of the respondents in this study are varied, therefore, it is classified into three ranges. Each range has a five-year age range. It is also assume that each age group has the same characteristics of individuals, both in terms of psychology, productivity, and performance. The distribution of respondents in the age grouping is as follows:

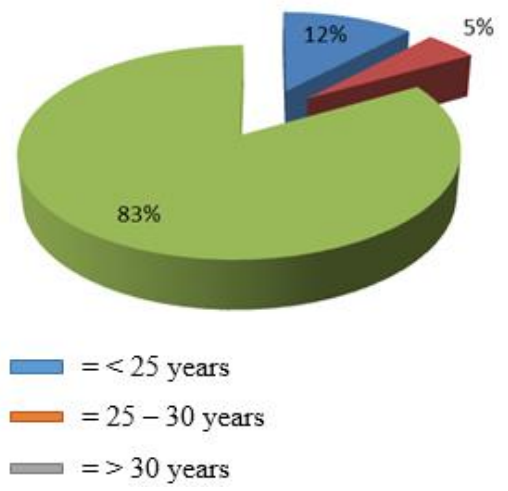

Fig. 2. Respondents based on age.

Based on the graph above, it can be said that the majority of respondents or employees in the age group > 30 years are 70 people $(83 \%)$.

3) Respondents based on the length of work: This study groups respondents into the range of tenure. The grouping of respondents' length of work is divided into three ranges. These ranges are less than 5 years, between 5 and 10 years, and longer than 10 years. The result of this grouping can be seen in the figure 3 below.

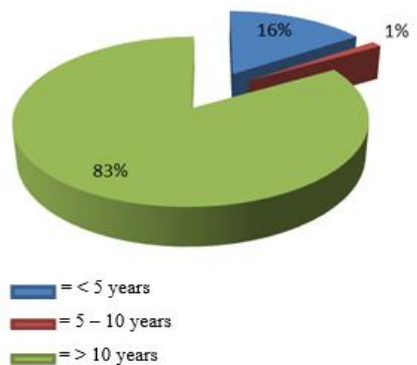

Fig. 3. Respondents base on length of work.

Based on the figure 3 above, it can be seen that most of the respondents in this study had worked for more than 10 years as many as 70 people $(83 \%)$.

\section{B. Validity and Reliability Test}

The results of validity test using SPSS version 20 for 3 variables (remuneration, modernization tax information system, and employee performance) showed that all questionnaire items have value of $\mathrm{r}$ or Corrected Item-Total Correlation higher than 0.3. Therefore, it can be concluded that all questionnaire items are valid. Tables below are the results of the validity test.

TABLE I. VALIDITY TEST OF REMUNERATION (X1)

\begin{tabular}{|r|r|r|r|r|}
\hline \multicolumn{5}{|c|}{ Item-Total Statistics } \\
\hline & $\begin{array}{c}\text { Scale Mean if } \\
\text { Item Deleted }\end{array}$ & $\begin{array}{c}\text { Scale Variance if } \\
\text { Item Deleted }\end{array}$ & $\begin{array}{c}\text { Corrected Item- } \\
\text { Total Correlation }\end{array}$ & $\begin{array}{c}\text { Cronbach's } \\
\text { Alpha if Item } \\
\text { Deleted }\end{array}$ \\
\hline X1.1 & 7,79 & 1,231 &, 510 &, 981 \\
\hline X1.2 & 7,96 &, 999 &, 846 &, 668 \\
\hline X1.3 & 7,99 &, 976 &, 834 &, 675 \\
\hline
\end{tabular}

TABLE II. VALIDITY TEST OF MODERNIZATION TAX INFORMATION SYSTEMS (X2)

\begin{tabular}{|r|r|r|r|r|}
\hline \multicolumn{7}{|c|}{ Item-Total Statistics } \\
\hline & $\begin{array}{c}\text { Scale Mean if } \\
\text { Item Deleted }\end{array}$ & $\begin{array}{c}\text { Scale Variance if } \\
\text { Item Deleted }\end{array}$ & $\begin{array}{c}\text { Corrected Item- } \\
\text { Total Correlation }\end{array}$ & $\begin{array}{c}\text { Cronbach's } \\
\text { Alpha if Item } \\
\text { Deleted }\end{array}$ \\
\hline X2.1 & 20,13 & 5,200 &, 413 &, 896 \\
\hline X2.2 & 20,42 & 4,680 &, 689 &, 853 \\
\hline X2.3 & 20,64 & 4,979 &, 487 &, 886 \\
\hline X2.4 & 20,56 & 4,177 &, 863 &, 821 \\
\hline X2.5 & 20,55 & 4,178 &, 886 &, 817 \\
\hline X2.6 & 20,62 & 4,383 &, 776 &, 838 \\
\hline
\end{tabular}

TABLE III. VALIDITY TEST OF EMPLOYEE PERFORMANCE (Y)

\begin{tabular}{|c|c|c|c|c|}
\hline \multicolumn{5}{|c|}{ Item-Total Statistics } \\
\hline & $\begin{array}{c}\text { Scale Mean if } \\
\text { Item Deleted }\end{array}$ & $\begin{array}{c}\text { Scale Variance if } \\
\text { Item Deleted }\end{array}$ & $\begin{array}{c}\text { Corrected Item- } \\
\text { Total Correlation }\end{array}$ & $\begin{array}{c}\text { Cronbach's } \\
\text { Alpha if Item } \\
\text { Deleted }\end{array}$ \\
\hline Y1 & 27,10 & 8,111 &, 318 &, 767 \\
\hline Y2 & 27,11 & 7,711 &, 335 &, 767 \\
\hline Y3 & 27,52 & 7,168 &, 439 &, 751 \\
\hline Y4 & 27,44 & 6,466 &, 646 &, 710 \\
\hline Y5 & 27,18 & 8,100 &, 413 &, 757 \\
\hline Y6 & 27,44 & 6,249 &, 672 &, 703 \\
\hline Y7 & 27,50 & 6,855 &, 551 &, 730 \\
\hline Y8 & 27,55 & 7,287 &, 395 &, 759 \\
\hline
\end{tabular}


TABLE VI. MULTICOLLINEARITY TEST

This study used the Cronbach Alpha formula to test the reliability of variables. The minimum Cronbach Alpha scale for a questionnaire to say reliable is higher than 0.6 [16]. If the Cronbach Alpha value is less than 0.6 or $60 \%$, then this indicates there are some respondents who answered inconsistently. The results of the reliability test of this study are as follows:

TABLE IV. RELIABILITY TEST

\begin{tabular}{|l|l|l|}
\hline \multicolumn{1}{|c|}{ Variables } & Cronbach's Alpha & \multicolumn{1}{|c|}{ Description } \\
\hline Remuneration $\left(\mathrm{X}_{1}\right)$ & 0,850 & Reliable \\
\hline $\begin{array}{l}\text { Modernization tax information } \\
\text { systems }\left(\mathrm{X}_{2}\right)\end{array}$ & 0,876 & Reliable \\
\hline Employee Performance $(\mathrm{Y})$ & 0,770 & Reliable \\
\hline
\end{tabular}

Source: Output of SPSS data processing

According to the SPSS output above, it can be seen that the Cronbach's Alpha values of all variables are higher than 0.60 or $60 \%$. Therefore, all statements on the remuneration variable (X1), modernization tax information systems variable $(\mathrm{X} 2)$ and employee performance variable (Y) are reliable.

\section{Classic Assumption Test}

1) Normality test: The normality test used of this study is the Kolmogorov-Smirnov test. In this test, it can be said normal if the significant value is greater than 0.05 . Following are the results of the normality test data in this study which were calculated by the SPSS 20 program.

TABLE V. NORMALITY TEST

\begin{tabular}{|l|l|r|}
\hline \multicolumn{2}{|c|}{ One-Sample Kolmogorov-Smirnov Test } \\
\hline \multicolumn{2}{|l|}{} & \multicolumn{1}{c|}{$\begin{array}{c}\text { Unstandardized } \\
\text { Residual }\end{array}$} \\
\hline \multirow{2}{*}{ Normal Parameters ${ }^{\mathrm{a}, \mathrm{b}}$} & Mean & 84 \\
\cline { 2 - 3 } & Std. Deviation & $0 \mathrm{E}-7$ \\
\hline \multirow{2}{*}{ Most Extreme Differences } & Absolute &, 066 \\
\cline { 2 - 3 } & Positive &,- 043 \\
\cline { 2 - 3 } & Negative &, 603 \\
\hline Kolmogorov-Smirnov Z &, 861 \\
\hline Asymp. Sig. (2-tailed)
\end{tabular}

a. Test distribution is Normal

b. Calculated from data.

Source: Output of SPSS data processing

Based on the results of data processing above, the significance value or Asymp.Sig. (2-tailed) is 0.861. Therefore, the data in the regression model is not affected by normality problems in other words the data is normally distributed, because the significance level is greater than 0.05 .

2) Multicollinearity: A good regression model should not have correlation among independent variables. To detect the presence or absence of multicollinearity in the regression model, the model should have a tolerance value above 0.1 and also have a VIF value below 10 .

The following multicollinearity test results for this study.

\begin{tabular}{|c|c|c|c|}
\hline \multicolumn{4}{|c|}{ Coefficients $^{\mathbf{a}}$} \\
\hline & \multirow[t]{2}{*}{ Model } & \multicolumn{2}{|c|}{ Collinearity Statistics } \\
\hline & & Tolerance & VIF \\
\hline \multirow[b]{2}{*}{1} & Remuneration & ,907 & 1,103 \\
\hline & $\begin{array}{|ll|}\begin{array}{l}\text { Modernization tax } \\
\text { systems }\end{array} & \text { information } \\
\end{array}$ & ,907 & 1,103 \\
\hline
\end{tabular}

Source: Output of SPSS data processing

Based on the table 6 above, it can be seen that the tolerance value is 0.9 and the VIF value is 1.1. Therefore, it can be concluded that multicollinearity does not occur.

3) Heteroscedasticity: A good model is a homocedasticity. It means that heteroscedasticity does not occur. The criteria for homocedasticity is if there is a clear pattern and points spread above and below the number 0 on the $\mathrm{Y}$ axis, then heteroscedasticity does not occur. The following is the heteroscedasticity test results of this study.

Scatterplot

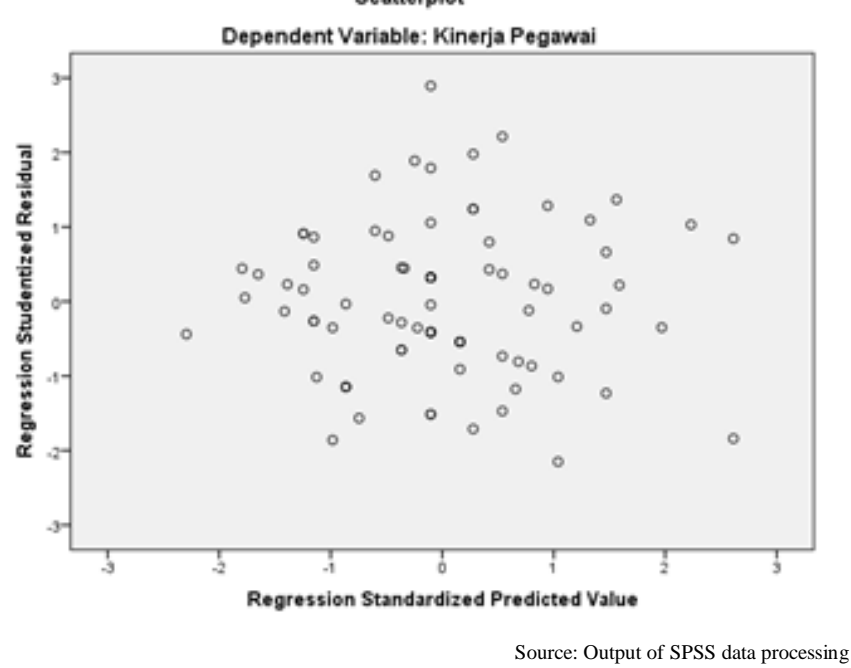

Fig. 4. Heteroscedasticity test.

Based on the figure above, it can be seen that the points are scattered randomly, both below and above the number 0 on the $\mathrm{Y}$ axis. Therefore, it can be concluded that in the regression model heteroscedasticity does not occur.

\section{Multiple Determination Coefficient Test}

Table 7 below is the results of multiple determination coefficient test.

TABLE VII. Multiple DETERMinAtion COEFFICIENT TEST

\begin{tabular}{l|l|l|l|l|}
\hline \multicolumn{7}{|c|}{ Model Summary } \\
\hline \multicolumn{1}{|c|}{ Model } & \multicolumn{2}{|c|}{$\boldsymbol{R}$ Square } & Adjusted R Square & $\begin{array}{c}\text { Std. Error of the } \\
\text { Estimate }\end{array}$ \\
\hline 1 & $1,447^{\mathrm{a}}$ &, 200 & 180 & \multicolumn{2}{c}{2,740} \\
\hline \\
$\begin{array}{l}\text { a. Predictors: } \\
\text { Remuneration }\end{array}$
\end{tabular}

Source: Output of SPSS data processing 
1) T-test: This test is to determine whether the independent variable has its own influence or partially on the dependent variable. To test the hypothesis is conducted by comparing the value of $t$-count with t-table. If t-count is greater than t-table, this means that there is a strong reason to accept hypothesis and vice versa. With $\mathrm{df}=\mathrm{n}$ - the number of variables $=84-3=81$, the t-table is 1.98969 . Following are the results of t-test.

TABLE IX. RESULT OF T-TEST

\begin{tabular}{|c|c|c|c|c|c|c|}
\hline \multicolumn{7}{|c|}{ Coefficients $^{\mathrm{a}}$} \\
\hline & \multirow[t]{2}{*}{ Model } & \multicolumn{2}{|c|}{$\begin{array}{l}\text { Unstandardized } \\
\text { Coefficients }\end{array}$} & \multirow{2}{*}{\begin{tabular}{|c|}
$\begin{array}{c}\text { Standardized } \\
\text { Coefficients }\end{array}$ \\
Beta \\
\end{tabular}} & \multirow[t]{2}{*}{$\mathbf{t}$} & \multirow[t]{2}{*}{ Sig. } \\
\hline & & $B$ & Std. Error & & & \\
\hline \multirow{3}{*}{1} & (Constant) & 16,415 & 3,320 & & 4,944 &, 000 \\
\hline & Remuneration & 515 & 211 & 255 & 2,440 &, 017 \\
\hline & $\begin{array}{l}\text { Modernization tax } \\
\text { information systems }\end{array}$ & 355 &, 124 & 298 & 2,858 &, 005 \\
\hline
\end{tabular}

a. Dependent Variable: Employee Performance

Source: Output of SPSS data processing

The description of the t-test results is as follows:

a) Remuneration variable: Based on the table above, the remuneration variable $(\mathrm{X} 1)$ obtained a t-value of 2.440 . So the value of $t$ is greater than the $t$-table value. The significance value obtained is equal to 017 or smaller than $\alpha=0.05$. Therefore, it can be concluded that remuneration partially influences employee performance.

b) Modernization tax information systems variable: Ttest results show that modernization tax information systems variable obtained a t-value of 2.858 which is greater than the t-table. Significance value of $0 . .005$ or smaller than $\alpha=0.05$. Therefore, modernization tax information systems variable partially influences the dependent variable, namely employee performance.

c) F-test: $\mathrm{F}$ test is used to measure the level of significance of the influence of remuneration and modernization on employee performance. The result of $F$ test can be seen in the table 10 .

TABLE X. RESULT OF F-TEST

\begin{tabular}{|c|l|l|l|l|l|c|}
\hline \multicolumn{2}{|c|}{ ANOVA $^{2}$} & \multicolumn{1}{c|}{$\begin{array}{c}\text { Sum of } \\
\text { Squares }\end{array}$} & $\boldsymbol{d f}$ & Mean Square & $\boldsymbol{F}$ & Sig. \\
\hline \multirow{4}{*}{1} & Regression & 152,224 & 2 & 76,112 & 10,140 &, $000^{\mathrm{b}}$ \\
\cline { 2 - 8 } & Residual & 608,014 & 81 & 7,506 & & \\
\cline { 2 - 8 } & Total & 760,238 & 83 & & & \\
\hline
\end{tabular}

a. Dependent Variable: Employee Performance

b. Predictors: (Constant), Modernization tax Information System, Remuneration

Source: Output of SPSS data processing

Based on the table above, the F-count value is 10.140 while the F-table value is 3.109311. F-count is greater than F-table with a significance value of 0,000 less than 0.05 . Therefore, it can be concluded that there is a significant influence between remuneration and modernization tax information system on employee performance. 


\section{G. Discussion}

Results of data analysis showed that remuneration is measured by two components, namely financial remuneration and non-financial remuneration significantly has a positive effect on the performance of Malang KPP employees. Therefore, it can be stated that the better the remuneration policy both financially and non-financially, the better the employee performance. Between financial and nonfinancial remuneration, the financial remuneration gives the highest contribution for employee performance. It can be seen from the highest means value, which is the indicator of financial remuneration. In an organization, especially KPP Madya Malang, policies related to remuneration such as salary or wages, incentives, health insurance and facilities provided will have a good impact on employee performance.

Remuneration has a significant positive effect on the performance of KPP Madya Malang employees. This result is supported by research conducted by Retnonigtyas which found that remuneration and employee involvement had a significant positive effect on employee performance at the Lembaga Sandi Negara. The results of the study were reinforced by the opinions of Hutapea and Thoha; Angliawati which states that remuneration within the company is implemented with the aim of making employees perform and make the employees can stay longer in the company $[8,9]$. It is also as a tool to increase employee motivation. Providing better remuneration will encourage employees to work more productive.

Modernization in this study is interpreted as a taxation information system needed to improve the ability of the Directorate General of Taxes to oversee the implementation of applicable taxation provisions with the principles of Good Governance. The purpose of establishing the Directorate General of Tax information system is to be able to produce a taxpayer profile that can be a supporting tool for the creation of accurate taxpayer data, by mobilizing the participation of various parties in monitoring taxpayer data. The process towards the modernization of the Directorate General of Taxes can be seen through various programs that have been carried out, including: e-reg, e-spt, e-filling, e-nofa, e-billing [3].

Results of data analysis showed that modernization tax information system has a significant positive effect on the performance of Malang KPP employees. Therefore, it can be stated that the better the modernization tax information system, the better the performance of employees. Indicator that gives the highest contribution to employee performance is e-SPT. This can be seen from the highest means value. E-SPT reporting is easier and more practical so that the workload of officers is lighter. The developments of technology and education have made the emergence of several alternatives in carrying out daily life. Like the e-SPT with the existence of these facilities can facilitate employees in carrying out tasks related to SPT reporting easier, and certainly more practical.

Modernization tax information system has a positive and significant effect on the performance of Malang KPP employees. The results are supported by research conducted by Saputra, Astuti and Rahardjo; Saleh and Septiyeni who stated that the application of modernization supported by the availability of adequate facilities and infrastructure would help employee performance $[17,18]$. Modernization of the taxation information system is needed to improve the ability of the Directorate General of Taxes to oversee the implementation of the applicable tax provisions with the principles of Good Governance. The application of modern taxation information systems will bring about the consequences of fundamental changes both regarding the organizational structure and service paradigm for taxpayers [10].

\section{CONCLUSION}

Remuneration has a significant positive effect on the performance of KPP Madya Malang employees. Remuneration has an effect on the performance as seen from the t-value of 2.440 is greater than the value of t-table with the significance obtained is 0.017 or below 0.05 . Modernization tax information system also has a significant positive effect on the performance of Malang KPP employees. Modernization tax information system has an effect on employee performance indicated by the $\mathrm{t}$-value of 2.858 is greater than t-table and the significance is 0.005 or below 0.05 . Finally, remuneration and modernization tax information system have a positive and significant effect on the performance of Malang KPP employees. The results are shown in the F-count value of 10,140 with a significance value of 0,000 .

\section{REFERENCES}

[1] M.S.P. Hasibuan, Manajemen Sumber Daya Manusia. Edisi Revisi. Jakarta: Penerbit Bumi Aksara, 2012.

[2] M. Surya, Bunga Rampai Guru dan Pendidikan. Jakarta: Balai Pustaka, 2004.

[3] E.S. Irianto, Pajak Kepemimpinan Dan Masa Depan: Kanwil DjP Jateng 1. Semarang: dreamlight apps, 2015.

[4] P.M. Long and B. Peter, "Instrumental work values and responses to HR practices A study of job satisfaction in a Chinese manufacturer," Personnel Review, vol. 47, pp. 60-73, 2018.

[5] T.A. Judge, R.F. Piccolo, N.P. Podsakoff, J.C. Shaw, and B.L. Rich, "The relationship between pay and job satisfaction: a meta-analysis of the literature," Journal of Vocational Behaviour, vol. 77, no. 2, pp. 157167, 2010.

[6] S.L. Rynes, B. Gerhart, and K.A. Minette, "The importance of pay in employee motivation: discrepancies between what people say and what they do," Human Resource Management, vol. 43, no. 4, pp. 381-394, 2004.

[7] R. Taris and J. Feij, "Longitudinal examination of the relationship between supplies-values fit and work outcomes," Applied Psychology, vol. 50, no. 1, pp. 52-80, 2001.

[8] R.Y. Angliawati, "Peran remunerasi terhadap Kualitas Pelayanan Publik: Theoretical Review," Ecodemica, vol. IV, no. 2, 2016.

[9] P. Hutapea and N. Thoha, Kompetensi Plus. Jakarta: Gramedia Pustaka Utama, 2008.

[10] L. Pandiangan, Modernisasi \& reformasi pelayanan perpajakan: berdasarkan UU terbaru. Jakarta: Elex Media Komputindo, 2008.

[11] K. Chang Lee, M. Kirlidog, S. Lee, and G. Gun Lim, "User evaluations of tax filing web sites: A comparative study of South Korea and Turkey,” Online Information Review, vol. 32, no. 6, pp. 842-859, 2008.

[12] N. Rysaka, C. Saleh, and S.P. Rengu, "Penerapan Sistem Elektronik dalam Pelayanan Perpajakan (Studi pada Kantor Pelayanan Pajak Pratama Malang Utara)," Jurusan Administrasi Publik (JAP), vol. 2, no. 3, 2013.

[13] Wibowo, Manajemen Kinerja. Jakarta: Rajawali Press, 2007. 
[17] R. Saputra, E.S. Astuti, and K. Rahardjo, “Analisis Penggunaan Aplikasi Sistem Informasi Direktorat Jenderal Pajak (SIDJP) dan Kinerja Pegawai (Studi pada Kantor Pelayanan Pajak Pratama Surabaya Gubeng)," Jurnal Perpajakan, vol. 3, no. 1, 2014.

[18] M. Saleh and Septiyeni, "Analisis Penerapan Modernisasi Administrasi Perpajakan dan Implikasinya terhadap Kinerja Account Representative," Jurnal Dinamika, vol. 1, no. 1, 2014. 